\title{
Mellopegma (Mollusca) from the Middle Cambrian of North Greenland
}

\author{
John S. Peel \\ Grønlands Geologiske Undersøgelse, Øster Voldgade 10, DK-1350 København K, Danmark.
}

During the last decade, the resurgence of interest in the non-trilobite faunas of the Cambrian has resulted in the description of many new taxa of problematic molluscs. One such form is the laterally compressed helcionellacean Mellopegma, originally described from the Middle Cambrian of Australia by Runnegar \& Jell (1976) but subsequently reported from the Lower Cambrian of China (Zhou \& Xiao, 1984). Mellopegma has now been identified from the Middle Cambrian of central North Greenland where it occurs as phosphatised internal moulds preserved in a manner similar to that of the original Australian specimens from the Currant Bush Limestone of Queensland.

Specimens from GGU collection 218832 from the Ekspedition Bræ Formation of the Brønlund Fjord Group show a similar range in morphological variation to that seen in the illustrations of the type species, M. georginensis, given by Runnegar \& Jell (1976, fig. 8B); they are readily assigned to that species. Associated microfauna include Pelagiella, inarticulate brachiopods, hyolithids and sponge spicules.

Specimens from GGU collection 271492 from the slightly older Henson Gletscher Formation of the Brønlund Fjord Group are less well preserved than those in GGU 218832 but probably belong to the same species. Associated microfossils in the prepared sample include Protowenella which was also originally described from the Currant Bush Limestone by Runnegar \& Jell (1976) but is now known from a number of other localities, e.g. the Middle Cambrian of Bornholm (Berg-Madsen \& Peel, 1978) and New Zealand (MacKinnon, 1985) and the Lower Cambrian of Maly Karatau, Soviet Union (Missarzhevsky \& Mambetov, 1981) and Anhui Province, China (Zhou \& Xiao, 1984). The present record is from the same horizon from which Protowenella was reported by Peel (1979). Chancelloria, archaeostracods, hyolithids, algae, inarticulate brachiopods and trilobite and echinoderm debris are also present in the residue from GGU 271492.

\section{References}

Berg-Madsen, V. \& Peel, J. S. 1978: Middle Cambrian monoplacophorans from Bornholm and Australia, and the systematic position of the bellerophontiform molluscs. Lethaia 11, 113-125.

MacKinnon, D. E. 1985: New Zealand late Middle Cambrian molluscs and the origin of the Rostroconchia and Bivalvia. Alcheringa 9, 65-81.

Missarzhevsky, V. V. \& Mambetov, A. M. 1981: Stratigraphy and fauna of Cambrian and Precambrian boundary beds of Maly Karatau. Trudy Akad. Nauk SSSR 326, 92 pp. [In Russian.]

Peel, J. S. 1979: Protowenella (Mollusca) from the Cambrian of Peary Land, eastern North Greenland. Rapp. Grønlands geol. Unders. 91, 92 (only).

Runnegar, B. \& Jell, P. A. 1976: Australian Middle Cambrian molluses and their bearing on early molluscan evolution. Alcheringa 1, 109-138.

Zhou Benhe \& Xiao Ligong 1984: Early Cambrian monoplacophorans and gastropods from Huinan and Huoqiu Counties, Anhui Province. Prof. Pap. Strat. Palaeont. 13, 125-140. [In Chinese, English summary.] 